\title{
A STRUCTURAL EQUATION MODEL: GREECE'S TOURISM DEMAND FOR TOURIST DESTINATION ${ }^{1}$
}

\author{
Prasert Chaitip $^{1}$, Chukiat Chaiboonsri², Sándor Kovács ${ }^{3}$ \& Péter Balogh ${ }^{4}$
}

\author{
${ }^{1}$ Faculty of Economics, Chiang Mai University, Chiang Mai, Thailand. E-mail: webadmin@econ.cmu.ac.th \\ ${ }^{2}$ Department of Economics, Bangalore University, India.E-mail: chukiat1973@yahoo.com \\ ${ }^{3}$ Department of Economic Analysis and Statistics, Faculty of Applied Economics and Rural Development, \\ Centre of Agricultural and Technical Sciences, University of Debrecen, 4032 Debrecen, Hungary. \\ E-mail: kovacss@agr.unideb.hu \\ ${ }^{4}$ Department of Economic Analysis and Statistics, Faculty of Applied Economics and Rural Development, \\ Centre of Agricultural and Technical Sciences, University of Debrecen, 4032 Debrecen, Hungary. \\ E-mail: baloghp@agr.unideb.hu
}

\begin{abstract}
Structural equation model (LISREL 8) was applied to test the causal relationships between tourist travel motivations and tourist destination. A survey containing Likert scale questions was conducted to collect data from 100 tourists who had travelled to Greece's tourist destination. With the help of factor analysis, four dimensions were identified for scales used in the study: travel cost satisfaction, tourism product, tourism product attributes, and tourism product management. Results indicated that the travel cost satisfaction of tourists has a positive influence on tourism product, tourism product attributes and tourism product management. Moreover, our results suggested that the tourist demographics has a positive influence on tourism product and tourism product attributes and has an insignificant relationship with tourism product management. Based on our findings the tourist demographics has not influence on tourism product management. However, these findings suggest that both the private tourism and the governmental tourism sector should develop a better management of tourist destinations so as to develop a stronger attraction of tourism, better amenities, a better accessibility, an appropriate image, to make tourism competitive and to keep tourism product prices at a reasonable level. The implications of the tourism demand model can be used for the public environmental policy-making process based mainly on reasons of interest, ideology or understanding.
\end{abstract}

Key words: Greece; Tourism demand; Greece's tourist destination; SEM model

\section{Introduction, objectives}

Architecture in ancient Greek was unique in its style. This short research traces the tourism development in Greek. In the face of the deepening of the world economic crisis, Greece remains optimistic about its tourism progression. Tourism is a major contributor to the balance of payments, while it is single of the few activities which would enable Greece to achieve competitive advantages through the distribution of labour in Europe. Thus it is a vital motivator of the Greek economy for reducing the deficit of the balance of payments, boosting employment, generating income, and contributing to regional development (Zacharatos 1989: 274; Truett 1987:178).

Greece has enjoyed a continuous growth in arrivals, since the early 1950s in spite of the lack of any comprehensive tourism demand analysis undertaken by the Greek National Tourism Organisation (GNTO). Several research documents addressed the tourism-demand issue for Greece (Psoinos 1994a, 1994b; GNTO 1985a; Tourismos ke Oikonomia
1993; NSSG 1983, 1985, 1987, 1990, 1993; Stavrou 1984, 1986a, 1986b).

Based on the above mentioned studies tourism industry is claimed to be one of the most important sectors of the Greek economy as it contributes to the increase of the international income and development of the labour market.

Tourism in Greece has developed faster till 1990 than in the rest of Europe and in the world. During 1990-2000 there was a huge decline in the growth rate of tourist arrivals, which is much grater in Greece than in Europe and in the world. This shows the fact that Greece is still a favourite tourist destination. On the other hand, the Greek tourism faces with a grater risk of a further decline in the number of arrivals, unless some drastic action would be taken.

However, Greece comes in the 15th place in the world classification of tourist destinations receiving 14,179,999 tourists in 2002 (National Statistical Service of Greece, provisional data). The major part $(94.3 \%)$ is originated from Europe $(68.9 \%$ from the EU15). By plane came $73.6 \%$ of foreign tourists, by sea $5.6 \%$, by road $20.1 \%$ and by train

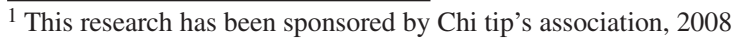


$0.6 \%$. The total number of nights spent in hotel accommodations by foreign and domestic tourists in 2001 $(61,567,209)$ marked a $0.43 \%$ increase compared to 2000 . The accommodation capacity of the 8,550 hotels is 330,970 rooms with 628,170 beds (2003). Another 450,000 beds are provided by some 28,000 secondary accommodation establishments. There are also 352 camping sites with 30,241 pitches and 1,005 bungalows. Besides the Hotel, Restaurants and Catering sector, there are about 8,000 travel agencies, rent-a-car agencies, and yacht-brokers. Tourism contribution to the GDP is estimated up to $8 \%$. The tourism receipts in 2002 were 10,285 euros. Employment in the tourism sector is estimated to reach 10\% (6.1\% direct employment and 3.9\% indirect) of the total employment in Greece (source: Tourism Statistics in Greece, real source, 1990-2003).

The above mentioned information proves that the Greek tourism industry will become an industry with high potentials that need to be continuously developed. Our study focuses on the tourist destination in Greece as the main idea is the development. In our research design the tourist destination consists of three part: 1) tourism product, 2 tourism product attribute, and 3) tourism product management. In this case these three parts would continuously be developed then not only the tourist would visit Greece again but also the number of visitors to Greece would increase. Therefore, the study focuses on the Greek tourism demand for tourist destination in Greece based on a structural equation model Approach (LISREL 8).

This research has the aim and objective of developing a structural equation model of the Greek tourism demand as well as using this model for explaining tourists' behaviour in Greece.

\section{Literature review}

\section{Demographic or Socio-economic segmentation}

Key factors such as age, gender, income, employment and education are often important and interrelated determinants of demand which often change over time (Kárpáti, 2009, Kárpáti and Varga and Nábrádi 2010). Weaver et al. (1994) and Cottrell (2003) found that age was a discriminating demographic variable that influenced holiday behaviour and choices. Younger people tend to be interested in adventurous activities such as wildlife viewing and beach holidays. With advances in age, individuals search for holiday activities that can give them more knowledge and understanding of issues outside their usual environment of life, particularly cultural activities (BongKoo 2001). Like age, occupation and education enhances the need for an individual to learn more about other people and how they live in different environments (Mok and Armstrong 1995). Therefore, travellers who are better educated and have high ranked occupations tend to search for more specific activities and experiences (Zimmer et al. 1995). Higher socioeconomic status increases the possibilities of engaging in people-centered activities due to greater access to information and increased awareness. Also more income enables individuals to spend more money during holidays. High-income earners prefer high-class activities and facilities (Odunga and Folmer 2004). This research also expects higher demographic or socio-economic status to have a positive impact on total expenditure due to preference for higher quality tourism product or tourism destination.

\section{Customer Satisfaction and Travel Cost Satisfaction}

It is indicated that factors such as personality, expectation, motivation, decision making, accommodation, and activities influence tourists' behaviour and determine the level of satisfaction (Jafari 2000). Customer satisfaction is a central concept in marketing because it is crucial to meeting the need of the customers (Spreng et al. 1996; Yi 1990). Firms deliver a product as well as satisfaction to the customer, and obtain profits in return. While customer satisfaction has been defined in many ways researchers generally agree that an evaluation process is an essential element underlying the customers' satisfaction (Yi 1990). Hunt (1997) defined satisfaction as "an evaluation rendered that the consumption experience was at least as good as it was supposed to be". Based on previous theoretical and empirical evidence, Engel and Blackwell (1982) conceptualized satisfaction as "an evaluation that the chosen alternative is consistent with prior beliefs with respect to that alternative". In term of economics, cost can be regarded as monetary service price and service time during which a service is provide (Murphy and Enis 1986). The effect of price is called price sensitivity, which is similar to price elasticity, which influences customers' purchase intention and behaviour (Zeithaml et al. 1985; Dodds et al. 1991). Customers may lose their purchasing intention and shift from the present service firm to another if the cost is higher than the benefit (Moonkyu and Cunningham 2001). According to the above mentioned literatures the travel cost satisfaction of tourist is higher when the cost of travel is lower. In the other hand, if the travel cost satisfaction of tourist is lower then it is expected then the cost of tourist' travel is higher. This research also expects higher travel cost satisfaction status to have a positive impact on total expenditure due to preference for tourism product or tourism destination.

\section{Tourism Product, Tourism Product Attributes and Tourism Product Management}

The tourism product is the synergistically perceived experience of an attraction, facilitated by a number of heterogeneous services. Apart from the attraction, the key services are transport, accommodation and hospitality (Gnoth 2005). The tourism product such as support services and attraction and tourist resources with one day's return travel time (WTO 2004). Brass (1997) suggests that tourism products can be classified into two main components: attractions and facilities. Attractions are those natural and 
human-made features and events that stimulate people to visit a destination. Together, the mix of destination attractions and facilities create a set of intangible "subjective experiences" for tourists known as a tourism product (Tourism Research Group 1992).

The tourism product includes physical goods, services, experiences, events, persons, places, properties, organizations, information and ideas contribute to the satisfaction of travellers (Smith 2001; Kothler 2001). The tourism products from the viewpoint of industrial stance can be apprehended on two levels: a) The total tourism product, consisting of a combination of all the service elements consumed by the tourist from the time he/she sets off home, to the time of return. This product can be an idea, an expectation, or a frame of mind, at the point of sale. b) The explicit products such as attractions, accommodation, transport and other facilities, are elements of the total tourism product. The product attributes refer to the various characteristics of product that influence a customer's decision to purchase or not to purchase the product (Swanson and Horridge 2004). These caracteristics are cleanness, beautiy, safety and protection of the environment (Dávid and Baros 2007; Dávid and Baros 2009; Tözsér and Dávid 2009). The tourism product management or the tourism destination management (Ritchie and Crouch 2003), consists of three parts: 1) destination competitiveness is the relative competitiveness of one destination to another. 2) destination performance involves economic measures, sustainability measures, visitor satisfaction measures, quality of management action measures. 3) successful goal achievement with respect to goals set by destination stakeholders. The destination management or tourism product management can be defined as "a system of managerial skills and activities used for coordinated planning and organizing of tourism for a particular destination" (Janečková and Vaštíková 1999). The destination management or tourism product management must address: a) Attractions: the motivators for the visit: (built (e.g. cathedrals/monuments), cultural (e.g. museums) and emotional or experiential triggers. b) Amenities: basic infrastructure such as utilities and roads direct services, accommodation, visitor information, catering and shopping facilities. c) Accessibility, d) Image and c) Price: (the cost of transport to and from the destination, accommodation, attractions, food and tour services) (Carter and Fabricius 2007). The destination management or tourism product management creates competitive advantage for your destination, and in the long run also advances sustainable development of competitive tourism (Lengyel, 2007). Our research focuses on the destination management or tourism product management, the attraction of tourism product, the amenities of tourism product, the accessibility to tourism product, the image of tourism product, the price of tourism product and the competitiveness of tourism product. We also suppose that both the higher travel cost satisfaction and the tourist demographics status have a positive impact on total expenditure due to preference for tourism destination (tourism product, tourism product attributes and tourism product management).

\section{METHODOLOGY}

Jöreskog and Sörbom have developed the LISREL Model Approach for creating a structural equation model (Table 1) with confirmatory factor analysis (Jöreskog and Sörbom 1989 and 1982). Also this approach is very popular in both social and economic research. The LISREL model (Jöreskog and Sörbom 2001), in its most general form, consists of a set of linear structural equations. Variables in the equation system may be either directly observed variables or unmeasured latent (theoretical) variables that are not observed but are related to observed variables. It is assumed in the model that there is a causal structure among a set of latent variables, and the observed variables are indicators of the latent variables. The model consists of two parts, the measurement and the structural equation model:

- The measurement model specifies how latent variables or hypothetical constructs depend upon or are indicated by the observed variables. It describes the measurement properties (reliabilities and validities) of the observed variables (Diamantopoulos and Siguaw, 2000).

- The structural equation model specifies the causal relationships among the latent variables, describes the causal effects, and assigns the explained and unexplained variance (Diamantopoulos and Siguaw, 2000; Jöreskog and Sörbom, 2001).

- The LISREL method estimates the unknown coefficients of the set of linear structural equations. It is particularly designed to accommodate models that include latent variables, measurement errors in both dependent and independent variables, reciprocal causation, simultaneity, and interdependence.

\section{Description of the model}

The full LISREL model for single samples is defined by the following three equations:

- The structural equation model: $\eta=\mathrm{B} \eta+\Gamma \xi+\varsigma$

- The measurement model for $\mathrm{y}: \mathrm{y}=\Lambda_{\mathrm{y}} \eta+\varepsilon$

- The measurement model for $\mathrm{x}: \mathrm{x}=\Lambda_{\mathrm{x}} \xi+\delta$

The terms in these models are defined as follows (Miller, 2002):

$\eta$ is a $\mathrm{m} \times 1$ random vector of latent dependent, or endogenous, variables

$\xi$ is a n x 1 random vector of latent independent, or exogenous, variables

$y$ is a p x1 vector of observed indicators of the dependent latent variables $h$

$\mathrm{x}$ is a $\mathrm{q} x$ 1vector of observed indicators of the independent latent variables $\mathrm{x}$

$\varepsilon \quad$ is a p x 1 vector of measurement errors in $y$

$\delta$ is a q x 1 vector of measurement errors in $x$

$\Lambda_{\mathrm{y}}$ is a p x m matrix of coefficients of the regression of $y$ on $\eta$

$\Lambda_{\mathrm{y}}$ is a $\mathrm{qx} \mathrm{n}$ matrix of coefficients of the regression of $\mathrm{x}$ on $\xi$ 
$\Gamma$ is a $\mathrm{m} x \mathrm{n}$ matrix of coefficients of the $\mathrm{x}$-variables in the structural relationship

$\mathrm{B}$ is a $\mathrm{m} \times \mathrm{m}$ matrix of coefficients of the h-variables in the structural relationship.

$\varsigma$ is a $\mathrm{m} \mathrm{x} 1$ vector of equation errors (random disturbances) in the structural relationship between $\eta$ and $\xi$

\section{Assumptions}

The random components in the LISREL model are assumed to satisfy the following minimal assumptions:

- $\varepsilon$ is uncorrelated with $\eta$

- $\delta$ is uncorrelated with $\xi$

- $\varsigma$ is uncorrelated with $\xi$

- $\varsigma$ is uncorrelated with $\varepsilon$ and $\delta$.

\section{Data collection, hypothesis}

\section{The conceptual framework}

Based on the literature review and research model (Figure 1), we intend to find the relationships among travel cost satisfaction, tourist demographics, tourism product, tourism product attributes and tourism product management by using a structural equation model of the Greek tourism demand for tourist destination. Two hypotheses have been used to test this presumption:

Hypothesis 1: Travel cost satisfaction will have a positive influence on tourism destination (tourism product, tourism product attributes and tourism product management)

Hypothesis 2: Tourist demographics will have a positive influence on tourism destination (tourism product, tourism product attributes and tourism product management)

Primary data was collected from 13 May to 13 June in 2008. Data have been collected from tourists arrivals to Greece in this period by a surveying method and the total number of questionnaires was 100 . The survey containing Likert scale questions (Table 1). The countries involved in the analysis were European countries (England, Germany, France, Sweden, Poland, Hungary, Italy) and non-European countries (America, Australia, Turkey, Russia, Canada). Almost all of them had an influence on the income of the Greek tourism industry in the research period. Data were also collected from Atina, Korinthos, Kavala, Pilipi, Thesaloniga and Kastoria, which are famous provinces for tourists' arrival to Greece (source: Greece's tourism organization, 2000).

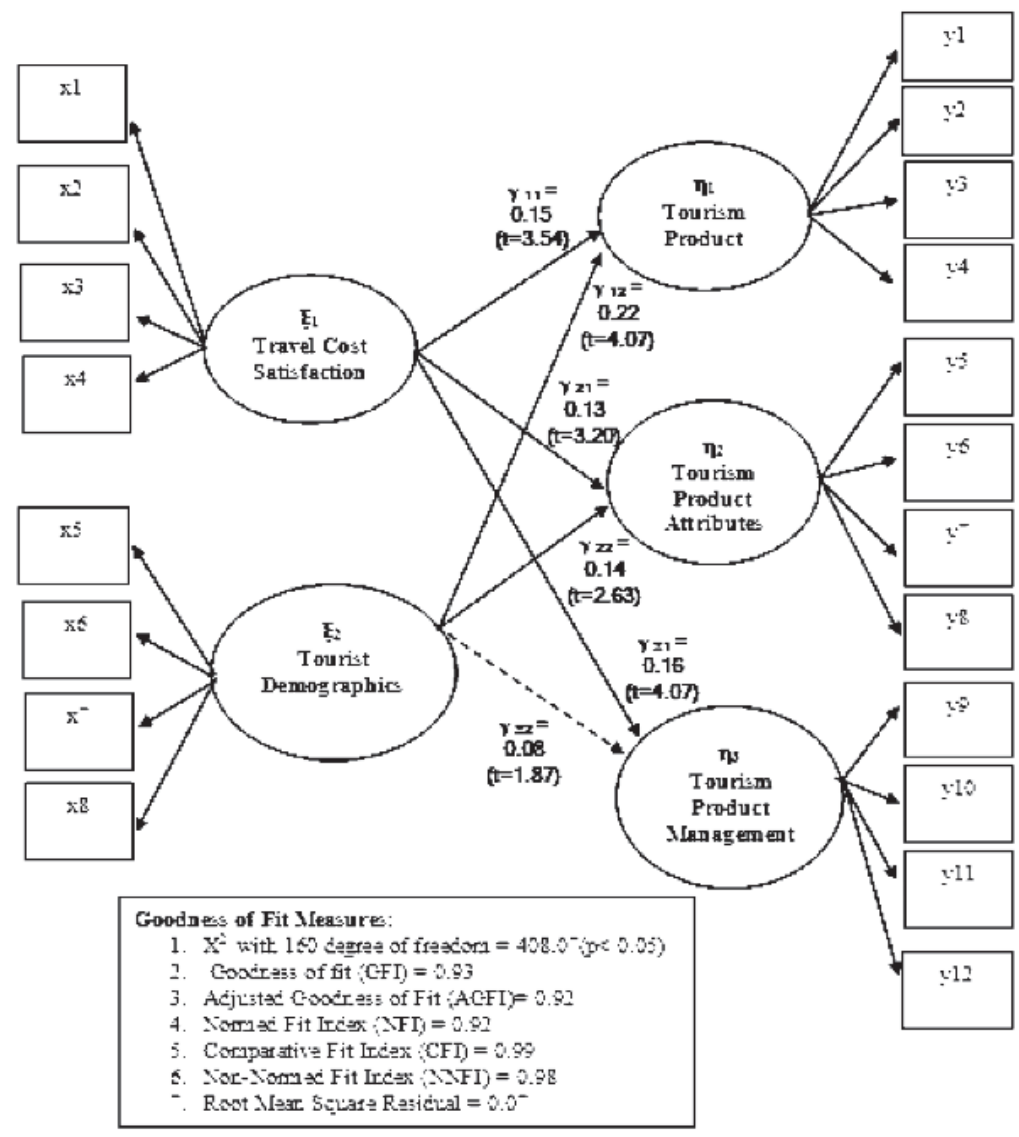

Figure 1: Hypothesized relationships between independent variables (Travel Cost and Tourist Demographics) and dependent variables (Tourism Product, Tourism Product Attributes and Tourism Product Management)

Source from: Swanson and Horridge (2004) and modified by Chaiboonsri and Chaitip (2008)

\section{Discussion of findings}

\section{The results of a structural equation model for Greece's Tourism Demand for tourist destination based on LISREL Model Approach}

Each of the observable variables was measured by several questions and the items for each variable were checked for construct validity and reliability using SPSS (Table 2). Construct validity was established by checking the result of the factor analysis, with all the items representing one factor accounting for about at least $58 \%$ of variance. Reliability refers to the degree of stability of the scale (Jackson et al. 1997). Reliability of the construct is demonstrated by checking the Cronbach alpha for the items for each construct and the correlation among the items for the construct. Table 8 gives the validity and reliability indices for the questionnaire items for each variable. All the items had reliability coefficient higher than 0.58 .

To test hypotheses 1 and 2 for causal relationships, the LISREL 8 program was used (for details concerning LISREL 8.53, see Jöreskog and Sörbom 2001). The LISREL model consists of a measurement model and a structural model. Figure 1 illustrates how latent variablestourism products, tourism product attributes, 
Table 1: The items of the questionnaire were used in the structural model

\begin{tabular}{|c|c|c|}
\hline Variable & Item & Questions \\
\hline Tourism Product & $\begin{array}{l}\text { PRODUCT } 1 \text { (y1) } \\
\text { PRODUCT } 2 \text { (y2) } \\
\text { PRODUCT } 4 \text { (y3) } \\
\text { PRODUCT } 8 \text { (y4) }\end{array}$ & $\begin{array}{l}\text { I was satisfied with the quality of tourist destinations: Sea, sand, beaches, } \\
\text { mountains or eco-tourism. } \\
\text { I was satisfied with the quality of tourist destinations: Cities, Hotels, and } \\
\text { Guesthouses, Department stores, Market place and Restaurants. } \\
\text { I was satisfied with the quality of tourist destinations: Sea sand, Beaches, } \\
\text { and Resorts on beaches and Islands. } \\
\text { I was satisfied with the quality of tourist destinations and I will come to Greece again. }\end{array}$ \\
\hline Tourism Product Attributes & $\begin{array}{l}\text { ATTRIBU1 (y5) } \\
\text { ATTRIBU2 (y6) } \\
\text { ATTRIBU3 (y7) } \\
\text { ATTRIBU4 (y8) }\end{array}$ & $\begin{array}{l}\text { I was satisfied with the attributes of tourist destinations: Sea, sand, beaches, mountain or } \\
\text { eco-tourism. (Clean, Beautiful, Safety and Not destroying the environment). } \\
\text { I was satisfied with the attributes of tourist destinations: Cities, Hotels, and Guesthouses, } \\
\text { Department stores, Market place and Restaurants. } \\
\text { (Clean, Beautiful, Safety and Not destroying the environment). } \\
\text { I was satisfied with the attributes of tourist destinations: Rural areas, resorts } \\
\text { and home stays. (Clean, Beautiful, Safety and Not destroying the environment). } \\
\text { I was satisfied with the attributes of tourist destinations: Sea, sand, beaches, and resorts on } \\
\text { beaches and Islands. (Clean, Beautiful, Safety and Not destroying the environment). }\end{array}$ \\
\hline Tourism Product management & $\begin{array}{l}\text { MANAGE1(y9) } \\
\text { MANAGE2 (y10) } \\
\text { MANAGE3 (y11) } \\
\text { MANAGE4 (y12) }\end{array}$ & $\begin{array}{l}\text { I was satisfied with the management of tourist destinations: Sea, sand, beaches, mountain } \\
\text { or eco-tourism (Attraction, Amenities, Accessibility, Image, Price and Competitive). } \\
\text { I was satisfied with the management of tourist destinations: Cities, Hotels, Guesthouses, } \\
\text { Department stores, Market place and Restaurants } \\
\text { (Attraction, Amenities, Accessibility, Image, Price and Competitive). } \\
\text { I was satisfied with the management of tourist destinations: Rural areas, resorts, home } \\
\text { stays. (Attraction, Amenities, Accessibility, Image, Price and Competitive). } \\
\text { I was satisfied with the management of tourist destinations: Sea, sand, beaches, and resorts } \\
\text { on beaches and Islands. (Attraction, Amenities, Accessibility, Image, Price and Competitive). }\end{array}$ \\
\hline Travel Cost & $\begin{array}{l}\operatorname{COST} 1(\mathrm{x} 1) \\
\operatorname{cosT} 2(\mathrm{x} 2) \\
\operatorname{cosT} 5(\mathrm{x} 3) \\
\operatorname{cosT} 7(\mathrm{x} 4)\end{array}$ & $\begin{array}{l}\text { Total cost of your travel to Greece's tourists destination. } \\
\text { Airline costs in Greece } \\
\text { Hotel cost and guesthouse costs for your trip. } \\
\text { Total cost of your domestics trip in Greece. }\end{array}$ \\
\hline Tourist demographic & $\begin{array}{l}\text { AGE }(x 5) \\
\text { EDUCAT }(x 6) \\
\text { INCOME }(x 7) \\
\text { SPEND }(x 8)\end{array}$ & $\begin{array}{l}\text { Age of tourist arrival to Greece's tourist destination. } \\
\text { Education of tourist arrival to Greece } \\
\text { Average income per month of tourist arrival to Greece's tourist destination. (US. Dollar) } \\
\text { Average total spending per visit to Greece's tourist destination of tourist (US. Dollar) }\end{array}$ \\
\hline
\end{tabular}

tourism product management, travel cost satisfaction, and tourist demographics-were measured (the measurement model) and how the latent variables were proposed to relate among one another (the structural equation model).

This research tested the model in Figure 1. and the final model is given in Figure 2. Significant relationships in model are indicated by solid arrow as well as insignificant relationships in this model are indicated by doted arrow. The chi-square statistic test whether the observed data fit the hypothesis if the proposed model, and a smaller chi-square value indicates a better fit ( $\operatorname{Sim}$ et al. 2006). However, for small sample size that might have slightly departed from normality, the chi-squares are not good model fit indicators (Sim et al. 2006). The chi-value in Figure 2 is significant $\left(\chi^{2}\right.$ with 160 degree of freedom $=408.07(\mathrm{p}<0.05)$ ). Other measures of fit include the goodness of fit index (GFI) and normed fit index (NFI). Both the GFI and NFI are always between zero and one, with one indicating a perfect fit while any value above 0.9 suggesting a good fit (Bentler and Bonett 1990). The model has a GFI of 0.93 and a NFI of 0.92 . This shows a good fit and the adjusted goodness of fit (AGFI) is
0.92 also this again shows a good fit. Similarly, the nonnormed fit index (NNFI) and the comparative fit index (CFI) are two additional measures ranging from 0 to 1 , where values close to or greater than 0.9 represent a reasonable mode fit (Sim et al. 2006). The NNFI and CFI for the model are 0.98 and 0.99 , respectively and finally, the root-mean squared residual (RMSR) shows the proportion of the variance not explained by the model. In general, a root mean squared residual of 0.08 or below indicates a reasonable model fit (Sim et al. 2006). The model has a RMSR of 0.07 also overall speaking; the GFI, AGFI, NFI, NNFI, CFI, and RMSR all indicate that the model has a good fit.

A review of the LISREL estimates and residuals in Table 3 reveals non-significant observed variables related to both travel cost satisfaction and tourist demographics: $\mathrm{x} 1, \mathrm{x} 3$ and $x 5$. And the LISREL estimates and residuals in the same table reveals non-significant observed variables related to tourism product: $\mathrm{y} 1$ as well as the LISREL estimates and residuals in the same tables reveals non-significant observed variables related to tourism product attributes: y5, y7 and y8. One again the LISREL estimates and residuals in the same 
Table 2: The reliability and validity of the items were used in a structure model

\begin{tabular}{|c|c|c|c|}
\hline Variable & Item & $\begin{array}{l}\text { Corrected item } \\
\text { Total Correlation }\end{array}$ & $\begin{array}{c}\text { Factor } \\
\text { Loading }\end{array}$ \\
\hline $\begin{array}{l}\text { Tourism Product } \\
1 \text { factor } 63 \% \text { of variance }\end{array}$ & $\begin{array}{l}\text { PRODUCT } 1 \\
\text { PRODUCT } 2 \\
\text { PRODUCT } 4 \\
\text { PRODUCT } 8\end{array}$ & $\begin{array}{c}0.70 \\
0.52 \\
0.61 \\
0.63 \\
\text { Alpha }=0.80\end{array}$ & $\begin{array}{l}0.85 \\
0.71 \\
0.79 \\
0.80\end{array}$ \\
\hline $\begin{array}{l}\text { Tourism Product Attributes } \\
1 \text { factor } 67 \% \text { of variance }\end{array}$ & $\begin{array}{l}\text { ATTRIBU1 } \\
\text { ATTRIBU2 } \\
\text { ATTRIBU3 } \\
\text { ATTRIBU4 }\end{array}$ & $\begin{array}{c}0.75 \\
0.59 \\
0.68 \\
0.63 \\
\text { Alpha }=0.83\end{array}$ & $\begin{array}{l}0.88 \\
0.75 \\
0.83 \\
0.79\end{array}$ \\
\hline $\begin{array}{l}\text { Tourism Product management } \\
1 \text { factor } 58 \% \text { of variance }\end{array}$ & $\begin{array}{l}\text { MANAGE1 } \\
\text { MANAGE2 } \\
\text { MANAGE4 } \\
\text { MANAGE5 }\end{array}$ & $\begin{array}{c}0.63 \\
0.51 \\
0.55 \\
0.52 \\
\text { Alpha }=0.58\end{array}$ & $\begin{array}{l}0.82 \\
0.72 \\
0.76 \\
0.73\end{array}$ \\
\hline $\begin{array}{l}\text { Travel Cost } \\
1 \text { factor } 71 \% \text { of variance }\end{array}$ & $\begin{array}{l}\text { COST1 } \\
\text { COST2 } \\
\text { COST5 } \\
\text { COST7 }\end{array}$ & $\begin{array}{c}0.83 \\
0.59 \\
0.73 \\
0.69 \\
\text { Alpha }=0.86\end{array}$ & $\begin{array}{l}0.91 \\
0.75 \\
0.86 \\
0.83\end{array}$ \\
\hline
\end{tabular}

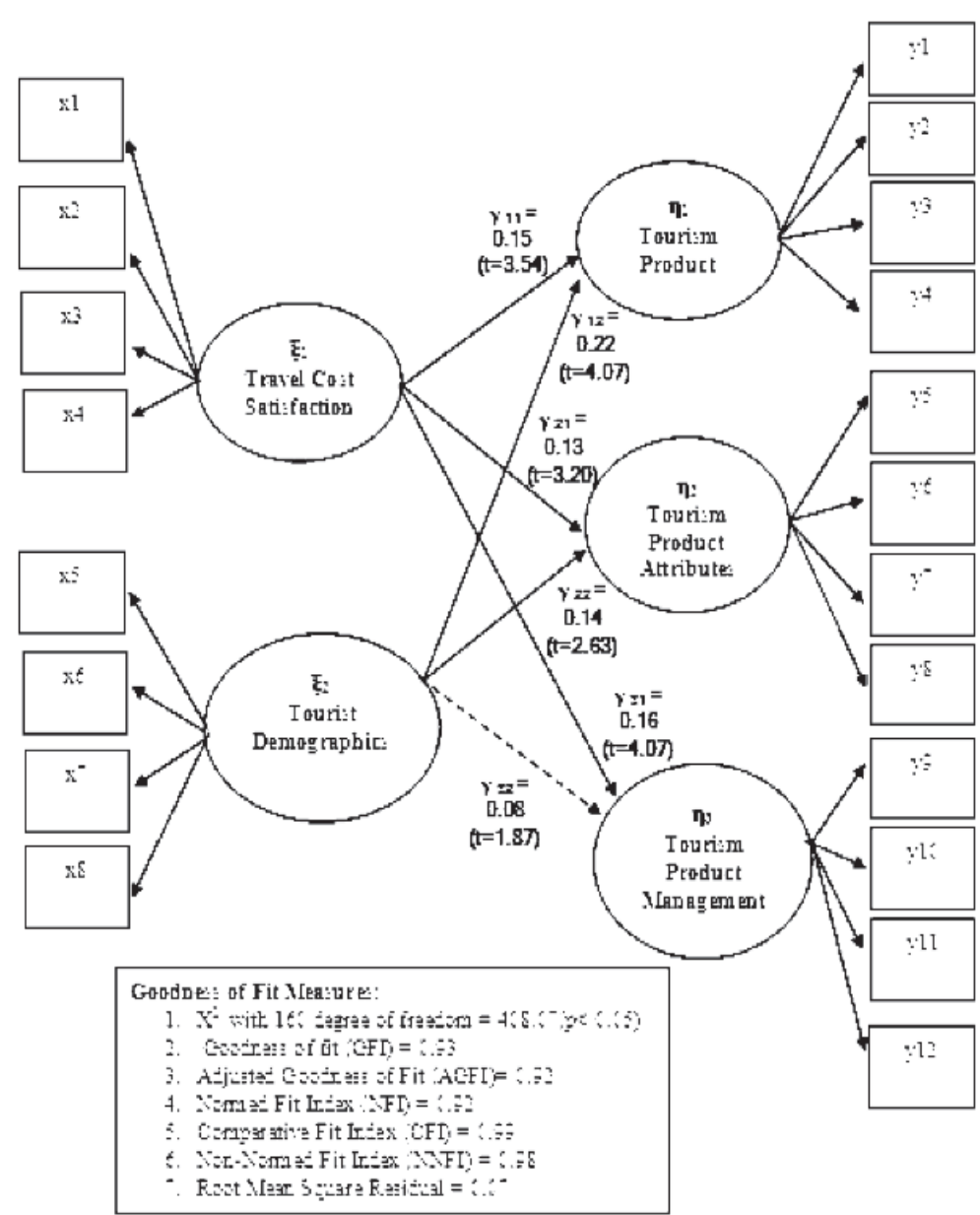

Figure 2: Final Model for Relationship Among Travel Cost Satisfaction, Tourists Demographics, Tourism Product, Tourism Product Attributes and Tourism Product Management*

* Significant relationships are denoted as solid arrow and insignificant relationships are denoted as dotted arrow.
Tables reveals non-significant observed variables related to tourism product management: y11.

Results indicated that the travel cost satisfaction of tourists has a positive influence on tourism product (with parameter 0.15 ), tourism product attributes (the estimated parameter is 0.13 ) and tourism product management (its parameter is 0.16 ). Moreover, our results suggested that the tourist demographics has a positive influence on tourism product (with parameter 0.22) and tourism product attributes (the estimated parameter is 0.14 ) and has an insignificant relationship with tourism product management. The significance level used in our analysis is set at 95 percent.

Consequently, the results of our research suggest that if the quality management of tourist destinations in Greece were more improved, the number of tourists travelling there would increase.

\section{Conclusion and implications}

This study attempted to determine the relationships between travel motivation (travel cost satisfaction and tourist demographics) and tourist destination in Greece (tourism product, tourism product attributes, and tourism product management). To test the causal relationships between these variables, a LISREL model incorporating measurement and structural equation modelling was developed. In our sample of 100 tourists, a positive effect was found between travel cost satisfaction and tourist destination (tourism product, tourism product attributes and tourism product management) as well as between tourist demographics and tourist destination (tourism product and tourism product attributes). Two conclusions emerge from the empirical analysis based on the LISREL Model.

Firstly, the travel cost satisfaction has a positive influence on tourism product as well as on tourism product attributes, and has a positive influence on tourism product management (see more detail in Figure 2). In term of economics, travel cost can be regarded as financial deal price and service time during which a service is provided. The effect of prices explained market segments arriving at different times to purchase the service. Tourists may lose their purchasing target and shift from the present service country to another if the expenditure is higher than their advantages. The travel cost satisfaction of tourists is higher when the travel cost is lower. On the other hand, tourists may increase their purchasing target when the travel cost satisfaction is higher. Consequently the travel cost is expected to be lower. Our research also suggests that higher travel cost satisfaction status has a more 
Table 3: LISREL estimates for measurement model (Relations of indicator variables to latent variables)

\begin{tabular}{|c|c|c|c|c|c|c|c|}
\hline Construct & Indicator & Path & LISREL Estimates & T-value & Residual & LISREL Estimates & T-value \\
\hline \multirow{4}{*}{$\begin{array}{c}\eta_{1} \text { Tourism } \\
\text { Product }\end{array}$} & y1 & $\lambda_{11}$ & $0.79 *$ & 7.15 & $\varepsilon_{1}$ & 0.30 & 1.61 \\
\hline & y2 & $\lambda_{21}$ & $0.52 *$ & 5.04 & $\varepsilon_{2}$ & $0.36^{*}$ & 2.41 \\
\hline & y3 & $\lambda_{31}$ & $0.50^{*}$ & 5.38 & $\varepsilon_{3}$ & $0.43 *$ & 2.58 \\
\hline & y4 & $\lambda_{41}$ & $0.71 *$ & 5.68 & $\varepsilon_{4}$ & $0.51 *$ & 2.92 \\
\hline \multirow{4}{*}{$\begin{array}{c}\eta_{2} \text { Tourism Product } \\
\text { Attributes }\end{array}$} & y5 & $\lambda_{52}$ & $0.74 *$ & 7.05 & $\varepsilon_{5}$ & 0.26 & 1.44 \\
\hline & y6 & $\lambda_{62}$ & $0.54 *$ & 4.85 & $\varepsilon_{6}$ & $0.36^{*}$ & 2.25 \\
\hline & y7 & $\lambda_{72}$ & $0.65^{*}$ & 5.22 & $\varepsilon_{7}$ & 0.28 & 1.67 \\
\hline & y8 & $\lambda_{82}$ & $0.50^{*}$ & 4.68 & $\varepsilon_{8}$ & 0.22 & 1.40 \\
\hline \multirow{4}{*}{$\begin{array}{c}\eta_{3} \text { Tourism Product } \\
\text { Management }\end{array}$} & y9 & $\lambda_{93}$ & $0.58^{*}$ & 7.04 & $\varepsilon_{9}$ & $0.40^{*}$ & 2.41 \\
\hline & y10 & $\lambda_{10.3}$ & $0.46^{*}$ & 2.94 & $\varepsilon_{10}$ & $0.53 *$ & 3.34 \\
\hline & y11 & $\lambda_{11.3}$ & $0.55^{*}$ & 3.20 & $\varepsilon_{11}$ & 0.30 & 1.84 \\
\hline & y12 & $\lambda_{12.3}$ & $0.67 *$ & 3.42 & $\varepsilon_{12}$ & $0.04 *$ & 2.27 \\
\hline \multirow[t]{4}{*}{$\xi_{1}$ Travel Cost } & $\mathrm{x} 1$ & $\lambda_{11}$ & $0.94 *$ & 11.54 & $\delta_{1}$ & 0.11 & 0.52 \\
\hline & $\mathrm{x} 2$ & $\lambda_{21}$ & $0.68 *$ & 9.86 & $\delta_{2}$ & $0.68 *$ & 3.90 \\
\hline & $\mathrm{x} 3$ & $\lambda_{31}$ & $0.84^{*}$ & 11.02 & $\delta_{3}$ & 0.32 & 1.67 \\
\hline & $\mathrm{x} 4$ & $\lambda_{41}$ & $0.82^{*}$ & 10.94 & $\delta_{4}$ & $0.56^{*}$ & 2.93 \\
\hline \multirow{4}{*}{$\begin{array}{c}\xi_{2} \text { Tourist } \\
\text { Demo graphics }\end{array}$} & $\mathrm{x} 5$ & $\lambda_{52}$ & $0.27^{*}$ & 3.46 & $\delta_{5}$ & 0.13 & 0.08 \\
\hline & x6 & $\lambda_{62}$ & $0.50 *$ & 5.88 & $\delta_{6}$ & $0.63 *$ & 3.76 \\
\hline & $\mathrm{x} 7$ & $\lambda_{72}$ & $0.63 *$ & 6.66 & $\delta_{7}$ & $0.54 *$ & 2.86 \\
\hline & $\mathrm{x} 8$ & $\lambda_{82}$ & $0.96^{*}$ & 7.29 & $\delta_{8}$ & $0.60 *$ & 2.07 \\
\hline
\end{tabular}

* LISREL estimates significant, $\mathrm{p}<0.05$

positive impact on total expenditure due to preference for tourism product or tourism destination. So to sum up, the travel cost satisfaction has a strong effect on the tourists' purchasing decisions.

Secondly, the tourist demographics has a positive influence on tourism product. Moreover, the tourist demographics also has a positive influence on tourism attributes. Age was a selective demographic variable that influenced holiday behaviour and choices. Young people tend to be interested in adventures to the Acropolis, while the architecture of ancient Greece achieved a unique level of accomplishment in the buildings on this area.

With advances in age, individuals search for holiday activities that can give them more knowledge and understanding of issues outside their usual tradition of life, particularly cultural activities. Like age, occupation and education enhances the need for an individual to learn more about Greek people and how people live in different historical environments. Therefore, travellers who are better educated and have high ranked occupations tend to search for more specific activities and experiences (Zimmer et. al. 1995). Higher socio-economic status increases the possibilities of engaging in people-centered activities due to greater access to information and increased awareness. Also more income enables individuals to spend more money during holidays. High-income earners prefer high-class activities and facilities (Odunga and Folmer 2004). This research also suggests that higher demographic or socioeconomic status would increase the total expenditure due to preference for higher quality tourism product or tourism destination.
Based on our findings, tourist demographics has no influence on tourism product management. However, these findings suggest that both the private tourism and the governmental tourism sector should develop a better management of tourist destinations so as to develop a stronger attraction of tourism, better amenities, a better accessibility, an appropriate image, to make tourism competitive and to keep tourism product prices at a reasonable level. The implications of the tourism demand model can be used for the public environmental policy-making process based mainly on reasons of interest, ideology or understanding.

\section{References}

Bentler, P. M. and Bonett, D. G. (1990): Comparative fit indices in structural models, Psychological Bulletin, 107 (2): 238-246.

Brass, J. L. (ed.) (1997): Community Tourism Assessment Handbook, Western Rural Development Centre, Utah State University. Available: http://www.google.com/search?q=user+satisfaction+and+product+d evelopment+bramwell (June, 2001).

Bongkoo, L. (2001): Considerations in developing marketing plan for cultural tourism utilizing a community's cultural resources, Paper presented at the Culturelink Regional Expert Meeting UNESCO, Dec. 6-7, 2001, Chuncheon, Korea.

Cottrell, S. P. (2003): Influence of sociodemographics and environmental attitudes on general responsible environmental behaviour among recreational boaters, Environmental Behaviour, 35 (3): 347-375.

Carter, R. and Fabricius, M. (2007): "UNWTO Conference in Topic is Creating competitive advantage for your destination", Budapest, UNWTO Consultants (TEAM tourism Consulting). 
Chaitip, P., Rangaswamy, N. and Chaiboonsri, C. (2006): 'Modeling International Tourism Demand in Thailand', Working Paper Series 3/2006, LSD Center Chiang-Mai, Thailand.

Chaiboonsri, C. and Chaitip, P. (2008): A Structural Equation Model: Thailand's International Tourism Demand for Tourist Destination, Annals of the University of Petrosani, Economics, Romania, VIII. (I.): 65-94.

Dávid, L. and Baros, Z. (2007): A Possible Use of Indicators for Sustainable Development in Tourism, Anatolia, 18(2): 349-355.

Dávid, L. and Baros, Z. (2009): Environmentally Sustainable Tourism: international and Hungarian relations, Gazdálkodás, 53: 80-91. English Special Edition.

Diamantopoulos, A. and Siguaw, J. A. (2000): Introducing LISREL, Thousand Oaks, CA: Sage.

Dodds, W.B., Monroe, K.B. and Grewal, D. (1991): Effects of Price, Brand, and Store Information on Buyers' Product Evaluations, Journal of Marketing Research, 28: 307-319.

Economist. (1993): Last Chance Sisyphus: A survey of Greece. Economist (22 May), 2-22.

Engle, J.F. and Blackwell, R.D. (1982): Consumer behavior, The Dryden Press, New York, NY.

Gnoth, J. (2005): "Strengthening Tourism SME Brands Department of Marketing", University of Otago, New Zealand.

GNTO. (1985a): Survey of attributes of foreign tourists 1984-1985 (in Greek), Greek National Statistical Services, Athens: GNTO.

Hunt, H. K. (1997): CS/D-overview and future research directions. In Hunt, K. H. (Eds), Conceptualization and measurement of consumer satisfaction and dissatisfaction, Marketing Science Institute, Cambridge, MA, pp. 455-488

Jackson, C. M., Chow, S. and Leitch, R. A. (1997): Toward an understanding of the behavioral intention to use and information system. Decision Sciences, 28(2), pp. 357-389

Jafari, J. (2000): ENCYCLOPEDIA OF TOURISM, p. 364.

Janečková, L. and Vaštíková, M. (1999): Marketing mest a obcí. Grada, Praha, p. 178.

Jöreskog, K, G. and Sörbom, D. (2001): LISREL VIII : User's Guide. Lincolnwood, IL: Scientific Software International.

Jöreskog, K. G. and Sörbom, D. (1982): "Recent Development in Structural Equation Modeling", Journal of Marketing Research, 4: 404-416.

Jöreskog, K. G. and Sörbom, D. (1989): LISREL 7 : User's Reference Guide. Chicago: Scientific Software International, Inc.

Kárpáti L. (2009): Correction Method on Fairs' Attraction Radius, APSTRACT, Applied Studies In Agribusiness And Commerce, Vol. 3. Numbers 1-2. 2009. p. 37-41.

Kárpáti L, Varga L, Nábrádi A. (2010): Economic Value of Agribusiness and Food Exhibitions in Eastern-Europe. In: Lisa O'Conner (ed.)e-Education, $e$-Business, $e$-Management and $e$-Learning: 2010 International Conference Proceedings (IC4E 2010). s.1., China, 2010.01.22-2010.01.24. Los Alamitos: IEEE Computer Society, 2010. pp. 527-531.

Kothler, P. (2001): A Framework for Marketing Management, Prentice-Hall, New Jersey.

Lengyel, M. (2007): "Destination Management Conceptual Framework and the case of Hungary", Heller Farkas College of Economics and Tourism, Budapest, Hungary.

Miller T. K. (2002): Structural Equation Modelling (SEM) using LISREL http://www.masil.org/documents/SEM.pdf
Mok, C. and Armstrong, R. W. (1995): Leisure travel destination choice criteria of Hong Kong residents, Journal of Travel and Tourism Marketing, 4 (1): 99-104.

Moonkyu, L. and Cunningham, L. F. (2001): A cost/benefit approach to understanding service loyalty, Journal of Services Marketing, 15(2): 113-130.

Murphy, P.E. and Enis, B. M. (1986): Classifying Products Strategically, Journal of Marketing, 50: 24-42.

NSSG (1987): Tourism Statistics 1984-1985, Athens: National Statistic Service of Greece.

NSSG (1990): Tourism Statistics 1986-1987, Athens: National Statistic Service of Greece.

NSSG (1993): Tourism Statistics 1988-1990, Athens: National Statistic Service of Greece.

NSSG (1983): Tourism Statistics 1981, Athens: National Statistic Service of Greece.

NSSG (1985): Tourism Statistics 1982-1983, Athens: National Statistic Service of Greece.

Psoinos, P. (1994a): Research on the foreign tourists' attributes in Greece (in Greek), Athens: Greek National Tourism Organization.

Psoinos, P. (1994b): Research on the attributes of foreigners who have never visited Greece (in Greek), Athens: Greek National Tourism Organization.

Odunga, P. and Folmer, H. (2004): Profiling Tourists for Balanced Utilization of Tourism-Based Resources in Kenya, Natural Resources Management, http://www.feem.it/Feem/Pub/Publications/ WPapers/default.htm.

Ritchie, J. R. B., and Crouch, G. I. (2003): The competitive destination: A sustainable tourism perspective, Wallingford, UK: CABI Publishing.

Sim, J., Mak B. and Jones, D. (2006): A Model of Customer Satisfaction and Retention for Hotels, Journal of Quality Assurance in Hospitality and Tourism, Vol. 7(3),pp.1-23

Smith, K. C. (2001): "Tourism product development: A case study of wildlife viewing in the Squamish valley". B.A. (Geography), Simon Fraser University.

Spreng, R.A., Machkenzie, S.C. and Olshavsky, S.W. (1996): A reexamination of minats of consumer satisfaction, Journal of Marketing, 60: 15-52.

Stavrou, S. (1984): Tourism Development in Greece during 1969-1982 (in Greek), Research and Development Division, Dept. A1. Athens: Greek National Tourism Organization.

Stavrou, S. (1986a): Research for the Characteristics of Foreign Tourist Demand in Greece in the Years 84/85 (in Greek), Research Division, Dept. A1. Athens: Greek National Tourism Organization.

Stavrou, S. (1986b): Critical Review of Tourism Activity in the Years 83/85 (in Greek), Research and Development Division, Dept. A1. Athens: Greek National Tourism Organization.

Swanson, K. K. and Horridge, P. E. (2004): A Structural Model for Sourvenir Consumption, Travel Activities, and Tourist Demographics, Journal of Travel Research, 42: 372-380.

Tourism Research Group (1992): Tourism In British Columbia: Status Report, Province Of British Columbia, Victoria.

Tourismos ke Oikonomia (1993): 20 years: 1973-1993 (in Greek), Special Issue, Athens.

Tözsér, A. and Dávid, L. (2009): Problems and Challenges of Tourism Destination Management in Hungary, In M. Smith, and L. 
Onderwater (Eds) Experiencing Difference Changing Tourism and Tourists' Experiences, (pp. 49-54). ATLAS Reflections 2009, Association for Tourism and Leisure Education (ATLAS).

Truett, D. and Truett, L. (1987): The response of tourism to international economic conditions: Greece, Mexico and Spain, Journal of Developing Areas, 21: 177-190.

Weaver, P. A., McCleary, K. W., Lepisto, L., and Damonte, L. T. (1994): The relationship of destination selection attributes to psychological, behavioural and demographic variables, Journal of Hospitality and Leisure Marketing, 2 (2): 93-109.

WTO (2004): "Destination Marketing for the $21^{\text {th }}$ Century and successful destination management and marketing fundamentals", Moscow, 23 March 2004, Esencan Tezibasoglu Coordinator for Destination Management.
Yi, Y. (1990): A critical review of consumer satisfaction, In Zeithaml, V. (Eds), Review of Marketing, American Marketing Association, Chicago, pp. 68-122.

Zacharatos, G. (1989): Theproblems andperspectives of tourisminGreece (in Greek), In H. Katsoulis, T. Giannitsis and P. Kazakos (Eds). Politics and Society, Economy and Foreign Relationships, (pp. 273-289). Athens: Papazisis.

Zeithaml, V.A., Parasuraman, A., and Berry, L.L. (1985): Problems and strategies in services marketing, Journal of Marketing, 49: 33-46.

Zimmer, Z., Brayley, R., and Searle, M. S. (1995): Whether to go and where to go: Identification of important influences on seniors' decisions to travel, Journal of Travel Research, 33 (3): 3-10. 